Section Editor

John J. Millichap, MD

\title{
Teaching NeuroImages: \\ Painful diplopia and Crohn disease
}

Think about orbital myositis

Damien Biotti, MD

Pierre Toulemonde, MD

David Brassat, PhD

Fabrice Bonneville, PhD

Correspondence to

Dr. Biotti:

biotti.d@chu-toulouse.fr

Download teaching slides: Neurology.org

\section{Figure Orbital MRI}
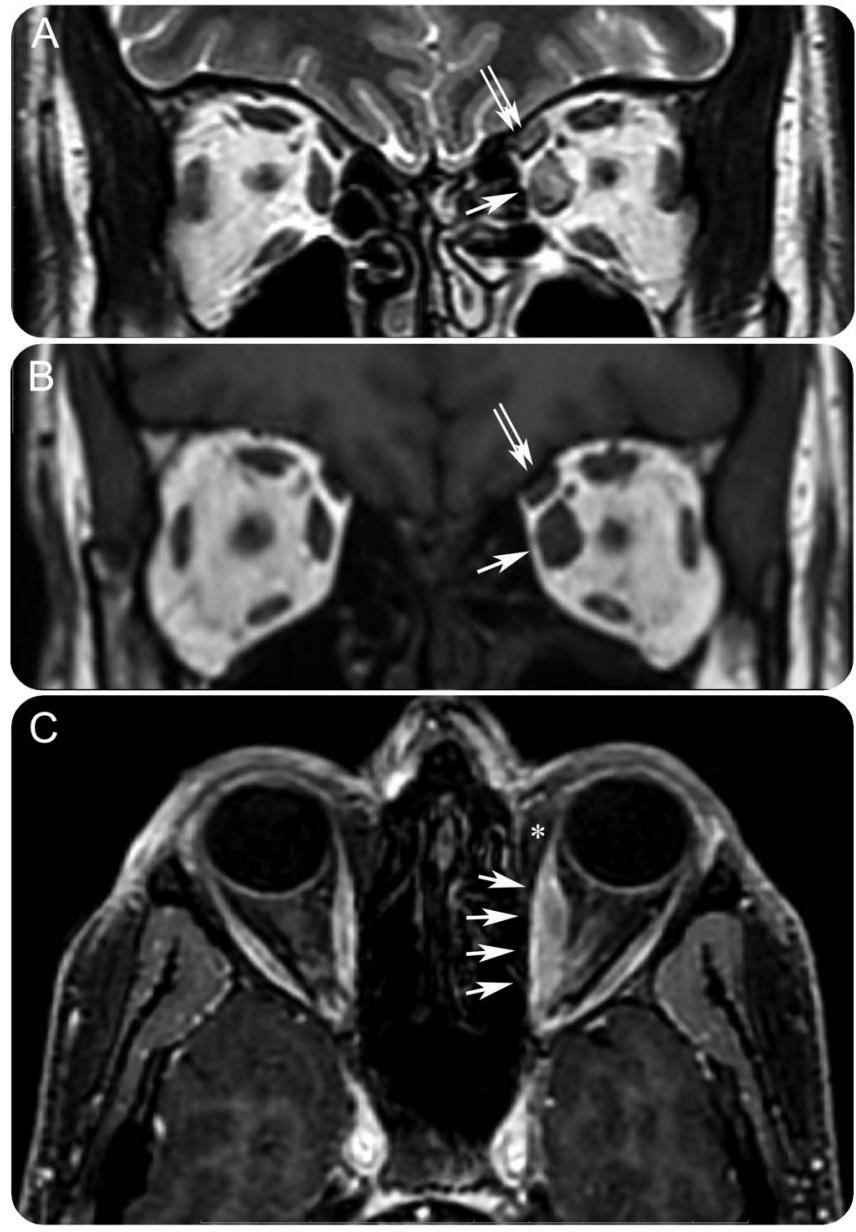

Coronal (A) T2-weighted and (B) T1-weighted images. (C) Axial gadolinium-enhanced T1-weighted image. Orbital MRI reveals (A-C) an enlargement and (B) enhancement of the left medial rectus (arrow) and superior oblique muscles (double arrow). Uncharacteristically, tendon insertions appeared spared (C: * medial rectus tendon insertion).

A 34-year-old man with Crohn disease (CD) treated with infliximab was seen for a 2-month history of painful binocular horizontal diplopia. Pain initially appeared in the right eye, then switched to the left eye 1 month later. Neuro-ophthalmologic testing revealed a painful limitation of the left eye during adduction and periorbital edema. Thyroid tests were normal. Orbital MRI showed features of orbital myositis (figure).

In $\mathrm{CD}$, extraintestinal ocular manifestations can occur, including episcleritis, scleritis, and uveitis. Orbital myositis is much rarer but can occur, in combination or

From Pole des Neurosciences, B4 Neurology Unit (D. Biotti, D. Brassat), and Department of Neuroradiology (F.B.), Hôpital Pierre-Paul-Riquet, CHU Purpan; Service d'Hépato-gastro-entérologie (P.T.), Clinique St Jean Du Languedoc; and INSERM UMR 1043 et Université Toulouse III (D. Brassat), France.

Go to Neurology.org for full disclosures. Funding information and disclosures deemed relevant by the authors, if any, are provided at the end of the article. 
not, with intestinal relapses. ${ }^{1,2}$ Oral steroids generally lead to a dramatic improvement, like in this patient.

\section{AUTHOR CONTRIBUTIONS}

D. Biotti: first author, corresponding author, principal investigator, neuro-ophthalmologic management. P. Toulemonde: Crohn disease management. D. Brassat: neurologic management. F. Bonneville: radiologic management.

\section{STUDY FUNDING}

No targeted funding reported.

\section{DISCLOSURE}

The authors report no disclosures relevant to the manuscript. Go to Neurology.org for full disclosures.

\section{REFERENCES}

1. Zenone T. Orbital myositis and Crohn's disease. Int J Rheum Dis 2014;17:481-482.

2. Verma S, Kroeker KI, Fedorak RN. Adalimumab for orbital myositis in a patient with Crohn's disease who discontinued infliximab: a case report and review of the literature. BMC Gastroenterol 2013;13:59. 


\section{Neurology}

\section{Teaching NeuroImages: Painful diplopia and Crohn disease: Think about orbital myositis}

Damien Biotti, Pierre Toulemonde, David Brassat, et al.

Neurology 2016;87; e68-e69

DOI 10.1212/WNL.0000000000002987

This information is current as of August 15, 2016

\section{Updated Information \& Services}

Supplementary Material

\section{References}

Subspecialty Collections

\section{Permissions \& Licensing}

Reprints including high resolution figures, can be found at: http://n.neurology.org/content/87/7/e68.full

Supplementary material can be found at: http://n.neurology.org/content/suppl/2016/08/15/WNL.0000000000002 987.DC1

This article cites 2 articles, 0 of which you can access for free at: http://n.neurology.org/content/87/7/e68.full\#ref-list-1

This article, along with others on similar topics, appears in the following collection(s):

All Neuro-ophthalmology

http://n.neurology.org/cgi/collection/all_neuroophthalmology Autoimmune diseases

http://n.neurology.org/cgi/collection/autoimmune_diseases

Diplopia (double vision)

http://n.neurology.org/cgi/collection/diplopia_double_vision

Muscle disease

http://n.neurology.org/cgi/collection/muscle_disease

Information about reproducing this article in parts (figures,tables) or in its entirety can be found online at:

http://www.neurology.org/about/about_the_journal\#permissions

Information about ordering reprints can be found online:

http://n.neurology.org/subscribers/advertise

Neurology ${ }^{\circledR}$ is the official journal of the American Academy of Neurology. Published continuously since 1951, it is now a weekly with 48 issues per year. Copyright @ 2016 American Academy of Neurology. All rights reserved. Print ISSN: 0028-3878. Online ISSN: 1526-632X.

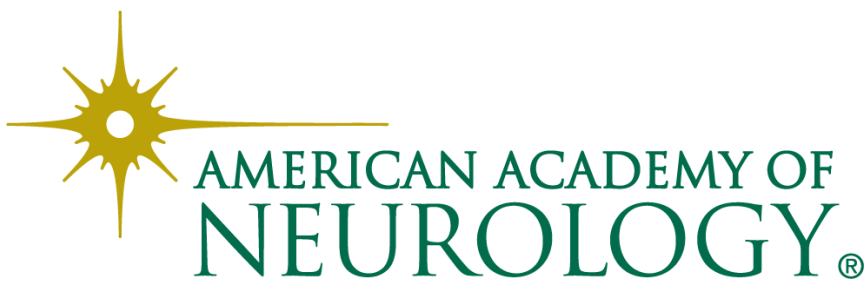

